Resona Jumal Ilmiah Pengabdian Masyarakat Vol. 1, No. 1 (2017) 46-51

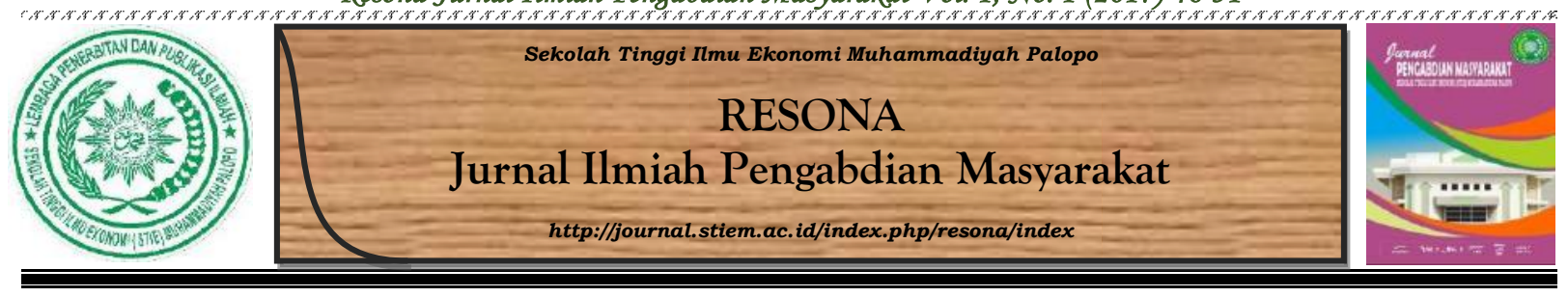

\title{
Pelatihan Manajemen Keuangan sebagai Upaya Peningkatan Daya Saing UMKM dalam Menghadapi MEA di Kecamatan Tomoni Kabupaten Luwu Timur
}

\author{
Junaidi
}

Sekolah Tinggi Ilmu Ekonomi Muhammadiyah Palopo

\section{INFO NASKAH

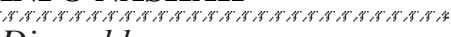 \\ Diserahkan \\ 23 November 2017 \\ Diterima dan disetujui \\ 26 Desember 2017

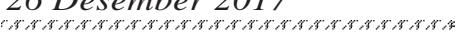

\section{Kata Kunci:}

Pelatihan

Pengembangan

Akuntansi

Manajemen keuangan

Manajemen keuangan

\begin{abstract}
ABSTRAK
Tujuan program Pengabdian Kepada Masyarakat (PKM) ini adalah memberikan pengetahuan dan keterampilan mengenai manajemen keuangan kepada para pelaku UMKM di Kota Palopo. Target khusus yaitu memberikan pengetahuan dan keterampilan kepada UMKM dalam pengembangan usaha melalui pelatihan dan bimbingan dalam meningkatkan manajemen keuangan. Adapun prospek pengembangan UMKM dikaji berdasarkan pada analisa keuangan. Rencana kegiatan program PKM ini adalah melakukan sosialisasi kepada pelaku UMKM, penyiapan peralatan pelatihan yang menunjang keberhasilan PKM, melakukan bimbingan terhadap pelaku UMKM dalam menyusun laporan keuangan, melakukan pelatihan dalam meningkatkan pengetahuan dan keterampilan baik melalui workshop maupun kegiatan-kegiatan lain, serta monitoring dan evaluasi kegiatan untuk menunjang keberhasilan dan keberlanjutan usaha.
\end{abstract}

\section{Pendahuluan}

Sesuai dengan filosofinya UMKM (Usaha Mikro, Kecil, dan Menengah) di Indonesia merupakan salah satu soko guru dan penyangga perekonomian selain koperasi Indonesia saat ini. Hal ini ditunjukkan dengan kontribusi sektor UMKM pada PDB (Produk Domestik Bruto) tahun 2011 yang mencapai 57 persen. Berdasarkan jumlah unit usaha yang mencapai 55 juta unit pada tahun 2011, sektor UMKM mampu menyediakan lapangan kerja bagi 101 juta orang atau sekitar 99 persen dari seluruh angkatan kerja Indonesia. UMKM telah menjadi penopang laju pertumbuhan ekonomi, penggerak sektor ril, dan penyerap tenaga kerja yang cukup signifikan melalui pengembangan kewirausahaan.

Selain itu, perkembangan jumlah UMKM dari tahun ke tahun semakin bertambah. 
Perkembangan UMKM baru terlihat dari sisi jumlahnya saja sedangkan dari segi kualitas dan perkembangan masih kurang memuaskan. Secara umum, salah satu kelemahan khususnya dalam aspek keuangan, hanya sedikit UMKM yang mengalami perkembangan dalam hal kinerja keuangannya. Hal ini tak lepas dari ketidaksadaran pelaku UMKM terhadap pentingnya pengelolaan keuangan perusahaan.

UMKM juga terbukti paling tangguh dalam menghadapi krisis moneter tahun 1997-1998 serta krisis global tahun 2008. Sebagian besar UMKM tetap bisa bertahan bukan hanya dalam krisis ekonomi tapi juga persaingan dari perusahaan-perusahaan yang berproduksi skala besar. Hal ini antara lain karena penggunaan bahan baku, tenaga kerja, dan orientasi pasar yang bersifat lokal. Pelaku UMKM pun semakin bertambah jumlahnya pascakrisis. Beberapa faktor yang dianggap menjadi penyebab terjadinya peningkatan jumlah pelaku UMKM tersebut antara lain: (a) produk UMKM merupakan barang konsumsi dengan tingkat proses kimiawi yang sangat rendah; (b) UMKM tidak mudah terpengaruh krisis ekonomi; (c) sebagian besar UMKM mengandalkan modal kepercayaan masyarakat sehingga pada saat krisis ekonomi, mereka terhindar dari beban bunga tinggi; (d) hampir tidak ada hambatan untuk keluar masuk dalam industri yang digeluti oleh UMKM; dan (e) banyaknya tenaga pengangguran akibat terbatasnya lapangan pekerjaan.

Meskipun jumlah pelaku UMKM cukup banyak dan memberikan kontribusi yang besar bagi perekonomian nasional, namun sebagian besar UMKM mengalami kesulitan dalam mengembangkan usahanya. Secara umum, persoalan yang dihadapi oleh UMKM meliputi akses permodalan, pemasaran, manajemen usaha dan keuangan, aspek legal dan perpajakan. Pengelolaan keuangan menjadi salah satu aspek penting bagi kemajuan perusahaan khususnya UMKM. Hal ini disebabkan para pelakunya dihadapkan pada masalah SDM. Pengelolaan keuangan dapat dilakukan melalui akuntansi walaupun dalam hal ini standar yang digunakan bersifat dasar dan sederhana. Akuntansi merupakan proses sistematis untuk menghasilkan informasi keuangan yang dapat digunakan untuk pengambilan keputusan bagi penggunanya.

Sepanjang UMKM masih menggunakan uang sebagai alat transaksinya, akuntansi sangat dibutuhkan oleh UMKM. Adanya laporan keuangan/akuntansi akan memberikan beberapa manfaat bagi pelaku UMKM, antara lain: (a) UMKM dapat mengetahui kinerja keuangan perusahaan terutama tingkat perputaran usaha dan modal; (b) UMKM dapat mengetahui, memilah, dan membedakan antara keuangan usaha dan keuangan pemilik; (c) UMKM dapat mengetahui posisi arus kas baik sumber maupun penggunaannya; (d) UMKM dapat membuat 
perencanaan anggaran yang tepat; (e) UMKM dapat menghitung pajak; dan (f) UMKM dapat mengetahui aliran uang tunai selama periode tertentu.

Banyak para pelaku UMKM mengelola usahanya dengan dasar kemampuan yang kurang memadai terutama aspek pengelolaan keuanganntanpa memiliki dasar pengetahuan maupun keterampilan mengenai manajemen usaha dan manajemen keuangan yang baik. Tidak jarang usaha hanya dijalankan dengan mengandalkan catatan seadanya serta insting dan pengalaman saja. Aspek-aspek manajemen usaha yang meliputi perencanaan usaha, pengorganisasian, implementasi, dan pengendalian usaha menjadi sesuatu yang jarang diperhatikan. Padahal itu merupakan aspek yang sangat vital dan sangat penting dalam membangun dan mengembangkan usaha karena kelanjutan UMKM dinilai dari tolok ukur kinerja keuangannya.

Banyak para pelaku UMKM merasa kesulitan jika harus menggunakan akuntansi dalam kegiatan bisnisnya. Hal ini dikarenakan terbatasnya tenaga dan kemampuan serta tidak adanya pedoman atau buku yang dapat dijadikan referensi untuk belajar mengelola keuangan UMKM. Buku-buku yang beredar saat ini memang belum ada yang fokus pada pengelolaan keuangan UMKM di Indonesia. Selain belum ada buku yang secara spesifik membahas transaksi dalam UMKM, banyak pelaku UMKM yang enggan membaca buku karena latar belakang pendidikan yang terbatas.

Berdasarkan permasalahan tersebut, perlu diadakan kegiatan pelatihan bagi pelaku UMKM dalam hal mengelola keuangan dengan menggunakan akuntansi. Program pelatihan yang ditawarkan berupa pelatihan akuntansi sederhana bagi UMKM. Akuntansi yang diajarkan adalah akuntansi sederhana yang disesuaikan dengan keadaan di UMKM namun tidak meyimpang dari standar dan peraturan yang ada. Pelatihan ini ditujukan bagi pelaku UMKM yang terdaftar di Dinas Koperasi dan Perdagangan Kota Palopo.

\section{Metode Pelaksanaan}

\section{Pelaksanaan}

Pelaksanaan kegiatan Pengabdian Kepada Masyarakat (PKM) ini dilakukan dengan menggunakan metode ceramah, tutorial, dan diskusi. Adapun tahapan pelaksanaan kegiatan pengabdian ini adalah sebagai berikut:

\section{a. Metode Ceramah}

Peserta diberikan wawasan mengenai pentingnya manajemen keuangan dalam memulai 
maupun menjalankan usaha. Langkah pertama diselenggarakan melalui metode ceramah selama $1,5 \mathrm{jam}$.

\section{b. Metode Tutorial}

Peserta pelatihan diberikan materi tentang penyusunan laporan keuangan, meliputi laporan laba rugi, laporan perubahan modal, neraca serta laporan arus kas. Materi ini disampaikan dalam bentuk tutorial disertai dengan latihan/studi kasus. Langkah kedua diselenggarakan selama 5 jam.

\section{c. Metode Diskusi}

Peserta pelatihan diberikan kesempatan untuk mendiskusikan permasalahan yang berkaitan dengan usaha yang sudah mereka jalani ataupun hal-hal yang ingin mereka tanyakan untuk memulai usaha. Langkah ketiga diselenggarakan selama 1,5 jam.

Disamping langkah 1, 2, dan 3 di atas, akan dilakukan kegiatan pendampingan untuk menyusun laporan keuangan usaha selama 8 jam dengan jadwal menyesuaikan peserta khalayak sasaran sehingga jumlah jam pengabdian masyarakat terpenuhi 16 jam.

\section{Evaluasi}

Kegiatan Pengabdian ini akan dievaluasi melalui kuesioner untuk mengetahui peningkatan pengetahuan manajemen keuangan yang akan didistribusikan sebelum dan sesudah kegiatan. Selain itu, melalui kegiatan pendampingan yang dilakukan setelah pelatihan, tingkat keberhasilan kegiatan pengabdian ini juga dapat diketahui. Berikut ini disajikan tabel evaluasi program pengabdian ini.

Tabel 1. Rancangan Evaluasi

\begin{tabular}{|l|l|l|}
\hline \multicolumn{1}{|c|}{ Tujuan } & Indikator Ketercapaian & \multicolumn{1}{c|}{ Tolok Ukur } \\
\hline $\begin{array}{l}\text { Peserta memiliki pengetahuan } \\
\text { tentang manajemen keuangan } \\
\text { usaha }\end{array}$ & $\begin{array}{l}\text { Pengetahuan tentang manajemen } \\
\text { keuangan usaha peserta } \\
\text { meningkat }\end{array}$ & $\begin{array}{l}\text { Peserta memahami pentingnya } \\
\text { manajemen keuangan usaha }\end{array}$ \\
\hline $\begin{array}{l}\text { Peserta mampu menyusun laporan } \\
\text { keuangan usaha }\end{array}$ & $\begin{array}{l}\text { Peserta mampu menyusun } \\
\text { laporan keuangan usaha }\end{array}$ & $\begin{array}{l}\text { Laporan keuangan yang disusun dapat } \\
\text { menjadi model laporan keuangan usaha } \\
\text { peserta }\end{array}$ \\
\hline
\end{tabular}

\section{Hasil dan Pembahasan}

Pelaksanaan pelatihan pada hari pertama Rabu 9 Agustus 2017 berjalan dengan lancar. Materi pertama yang diberikan adalah faktor-faktor yang menyebabkan terhambatnya 
pertumbukan dan kemajuan UMKM, salah satunya kendala SDM dan pengetahuan manajemen keuangan serta solusinya dengan memberikan pengenalan atau pendahuluan mengenai akuntansi. Pemateri memberikan penjelasan pentingnya akuntansi bagi UMKM. Sebagian besar audiens belum mengerti fungsi akuntansi, bahkan sebagian besar peserta pelatihan menganggap bahwa akuntansi adalah bidang yang rumit, susah, merepotkan, menghabiskan waktu. Materi pertama ini diisi dengan penguatan pentingnya akuntansi bagi usaha kecil (UMKM).

Setelah diperoleh kesepakatan tentang konsep UMKM, dilanjutkan dengan fungsi pelaporan keuangan bagi etitas. Setelah acara ishoma selama satu jam acara dilanjutkan dengan materi kedua mengenai transaksi-transaksi akuntansi UMKM. Pada sesi ini, masingmasing audiens diminta menjelaskan aktivitas operasi masing-masing usaha mereka. Selanjutnya diidentifikasi aktivitas-aktivitas ekonomi dan aktivitas nonekonomi. Berdasarkan aktivitas ekonomi yang telah diidentifikasi, selanjutnya dilakukan pencatatan akuntansi. Aktivitas yang diidentifikasi tersebut diawali dari aktivitas memulai usaha (investasi awal), transaksi pembelian bahan baku, pembelanjaan/pengeluaran, pemasukan/penerimaan, dan lain-lain. Setelah mencatat transaksi akuntansi, materi berikutnya menyusun laporan keuangan. Sebagai latihan, peserta pelatihan diminta membuat laporan keuangan sederhana berdasarkan contoh yang ada. Latihan ini berakhir pada pukul 15.00 sore.

Pada sesi tearkhir pelatihan ini, peserta diminta mengumpulkan dan mencatat transaksi usaha berdasarkan bidang masing-masing yang telah disiapkan dari rumah. Pada sesi awal ini peserta bertanya dan berdiskusi tentang transaksi dan pencatatan yang telah mereka buat. Beberapa dari perserta masih kebingungan mencatat transaksi akuntansi. Sesi pertama ini cukup menyita waktu karena pembahasan transaksi dan pencatatan akuntansi dilakukan satu per satu. Setelah semua peserta menyelesaikan pencatatan transaksi akuntansi, peserta beristirahat untuk makan siang dan melakukan ibadah siang. Setelah beristirahat, diskusi dilanjutkan membahas penyusunan laporan keuangan. Pada sesi terakhir ini peserta diminta menyusun laporan keuangan berdasarkan transaksi akuntansi yang telah mereka buat. Kegiatan pelatihan diakhiri pada jam 15.00. Selanjutnya dilakukan pendampingan kepada peserta pelatihan akuntansi UMKM secara mandiri di masing-masing tempat.

\section{Simpulan dan Saran}

Pemberdayaan sumber daya manusia harus dilandasi dengan kondisi di masyarakat. Para pelaku UMKM yang dicitrakan sebagai individu dan kelompok masyarakat marjinal. Padahal 
pada hakekatnya mereka adalah warga masyarakat yang mmeiliki kesempatan sama dengan komunitas masyarakat lainnya. Untuk itu diperlukan upaya pemberdayaan yang dalam wacana pembangunan masyarakat dihubungkan dengan konsep mandiri, partisipasi, jaringan kerja, dan keadilan. Permberdayaan masyarakat mengandung arti mengembangkan kondisi dan situasi sedemikian rupa sehingga masyarakat memiliki daya dan kesempatan untuk mengembangkan kehidupannya. Sebaiknya masyarakat harus terlibat dalam proses tersebut sehingga mereka dapat lebih memperhatikan hidupnya untuk memperoleh rasa percaya diri, memiliki harga diri dan pengetahuan untuk mengembangkan keahlian baru.

Pemerintah sebagai agen perubahan dapat menerapkan kebijakan pemberdayaan masyarakat dengan tiga arah tujuan, yaitu enabling, empowering, dan protecting. Enabling maksudnya menciptakan suasana atau iklim yang memungkinkan potensi masyarakat untuk berkembang. Empowering, bertujuan untuk memperkuat potensi atau daya yang dimiliki oleh rakyat dengan dengan menerapkan langkah-langkah nyata.

\section{Daftar Pustaka}

Admin Keu LSM. Pengelolaan Keuangan Bagi UMKM. http://keuanganlsm.com/pengelolaan-keuangan-bagi-ukm/ Diakses pada 25 Februari 2017.

Baskoro, F.M. 2014. Lima Tips Cerdas Mengelola Keuangan UMKM. http://www.beritasatu.com/ekonomi/173156-lima-tips-cerdasmengelola-keuanganumkm.html. Diakses pada 25 Februari 2017.

Sagoro, E.M. 2012. Akuntansi Tanpa Stres. Yogyakarta: AB Publiser.

Warsono, S. 2009. Akuntansi ternyata Logis dan Mudah. Yogyakarta: Asgard Chapter. 